\title{
The influence of crop residues in vertical soil mobility of potassium
}

\author{
Mobilidade do potássio no solo em função de diferentes \\ tipos e doses de resíduos vegetais
}

\author{
Osmar Rodrigues Brito ${ }^{*}$; Tiago Santos Telles ${ }^{2}$; Jenniffer Aparecida Schnitzer ${ }^{3}$; \\ Guilherme Garcia Gaspar"; Maria de Fátima Guimarães ${ }^{1}$
}

\begin{abstract}
This study has been developed to evaluate the influence of applying different types and doses of crop residues on potassium (K) mobility in soil columns. Rhodic Haplustox samples were collected at depths of $0.0-0.10,0.10-0.20$ and $0.20-0.30 \mathrm{~m}$ and used to create such soil columns, keeping the same profile distribution. The experimental design was randomized with three replications and the tested treatments were organized in a $4 \times 4$ factorial arrangement: 4 types of crop residues (brachiaria + sunflower; Mix (cultivated radish+oat+winter vetch); cultivated radish and wheat) and 4 doses of residues $(0,10,15$, and $20 \mathrm{Mg} \mathrm{ha}^{-1}$ ). The grinded and dried residues were applied to the surface of the columns, which were then irrigated with distilled water and incubated for 10 days to stabilize the reactions. After incubation, the soil columns were disassembled and separated into $0.05 \mathrm{~m}$ layers $(0.0-0.05,0.05-0.10,0.10-0.15$, $0.15-0.20,0.20-0.25$ and $0.25-0.30 \mathrm{~m})$. The samples of each layer were dried, sieved and analyzed to determine the amount of exchangeable $\mathrm{K}$. The results obtained indicated that surface application of crop residues alters soil levels of exchangeable potassium, especially in the 0.0-0.05 m layer. Increases in residue doses may cause a significant and linear increase in exchangeable $\mathrm{K}$ content in the $0.0-0.05$, $0.05-0.10$ and $0.10-0.15 \mathrm{~m}$ soil layers. Superficial application of residues of cultivated radish and Mix produced the largest increases in levels of exchangeable $\mathrm{K}$, reaching depths of $0.30 \mathrm{~m}$. Increases in potassium adsorption in the soil surface layers reduces the need for potassium fertilization and can reduce production costs and environmental pollution.
\end{abstract}

Key words: Cover crops, leaching, nutrient cycling, no-tillage, soil fertility

\section{Resumo}

O trabalho foi desenvolvido com o objetivo de avaliar a influência da aplicação de diferentes tipos e doses de resíduos vegetais na mobilidade do potássio (K) em colunas de solo. Para tanto, foram coletadas amostras de um Latossolo Vermelho eutroférrico, nas profundidades de 0.0-0.10, 0.10-0.20 e 0.20-0.30 m, que foram utilizados para montagem das colunas de solo, mantendo a mesma distribuição do perfil. O delineamento experimental empregado foi o inteiramente casualizado, com 3 repetições e os tratamentos testados constituíram um fatorial $4 \times 4$, em que os fatores foram 4 tipos de resíduos vegetais $(\mathrm{B}+\mathrm{G}=$ brachiaria + girassol; $\mathrm{Mix}=$ nabo forrageiro + aveia-preta + ervilhaca peluda; $\mathrm{NF}=$ nabo forrageiro; $\mathrm{T}=$ trigo) e 4 doses de resíduos $\left(0,10,15\right.$ e $\left.20 \mathrm{Mg} \mathrm{ha}^{-1}\right)$. Os resíduos moídos e secos foram aplicados na superfície das colunas que posteriormente foram irrigadas com água destilada e incubadas por 10 dias para estabilização das reações e equilíbrio salino. Após esse período procedeu-se a desmontagem das mesmas separando o solo em camadas correspondente as profundidades de $0.0-0.05$,

\footnotetext{
${ }^{1}$ Profs. Drs., Associados, Dept ${ }^{\circ}$ de Agronomia, Centro de Ciências Agrárias, Universidade Estadual de Londrina, UEL, Londrina, PR, Brasil.E-mail: osmar@uel.br; mfatima@uel.br

2 Dr. em Agronomia, Pesquisador, Instituto Agronômico do Paraná, IAPAR, Londrina, PR, Brasil. E-mail: telles@iapar.br

${ }^{3} \mathrm{Dr}^{\mathrm{a}}$ em Agronomia, Bióloga, UEL, Londrina, PR, Brasil. E-mail: je_uel@yahoo.com.br

${ }^{4}$ MS em Agronomia, Eng ${ }^{\circ}$ Agr ${ }^{\circ}$, UEL, Londrina, PR, Brasil. E-mail: guilhermegarciagaspar@yahoo.com.br

* Author for correspondence
} 
$0.05-0.10,0.10-0.15,0.15-0.20,0.20-0.25$ e $0.25-0.30 \mathrm{~m}$. As amostras de cada camada foram secas, tamisadas e analisadas para determinação do teor de $\mathrm{K}$ trocável. Os resultados obtidos indicam que a aplicação superficial de resíduos de culturas altera os teores de potássio trocável do solo, especialmente na camada 0.0-0.05 m. Aumentando as doses de resíduos pode-se aumentar significativa e linearmente os teores de K trocável do solo nas camadas $0.0-0.05,0.05-0.10,0.10-0.15 \mathrm{~m}$. Os resíduos da cultura de nabo forrageiro e do Mix (nabo forrageiro + aveia-preta + ervilhaca peluda) foram os que determinaram os maiores aumentos nos teores do $\mathrm{K}$ trocável do solo, podendo atingir profundidades de até $0.30 \mathrm{~m}$. $\mathrm{O}$ aumento na adsorção do K nas camadas superficiais do solo indica uma menor necessidade de aplicação de adubos potássicos, podendo reduzir os custos de produção e a poluição ambiental.

Palavras-chave: Cobertura vegetal, lixiviação, ciclagem de nutrientes, plantio direto, fertilidade do solo

\section{Introduction}

The movement of solutes and nutrients in the soil depends on its mineralogy and organic matter content (SOLLINS; ROBERTSON; UEHARA, 1988), nutrient concentrations and the density of electric charges in the exchange complex (QAFOKU; SUMNER, 2001), water content (FESCH et al., 1998; PADILLA; YEH; CONKLIN, 1999) and predominant environmental conditions (HESTERBERG, 1998; KABATA-PENDIAS, 2004).

In the case of potassium, vertical movement in the soil depends on cation exchange capacity (CEC) and its relationship with other adsorbed ions, especially basic cations such as $\mathrm{Ca}^{2+}, \mathrm{Mg}^{2+}, \mathrm{NH}_{4}^{+}$ and $\mathrm{Na}^{+}$(TISDALE; NELSON; BEATON, 1985). Typically the adsorption of cations on the surface of the colloids occurs obeying preferential exchange series, which are regulated by the amount of positive charge (valence) and size of the hydrated ion, whose force of attraction decreases in the following order: $\mathrm{Al}^{3+}>\mathrm{Ca}^{2+}>\mathrm{Mg}^{2+}>\mathrm{K}^{+}>\mathrm{Na}^{+}$. However, in tillage areas, surface accumulation of organic residues occurs, which during the decomposition process release large quantities of various organic acids (FRANCHINI et al., 2001). Organic acids of low molecular weight interfere with processes releasing and mobilizing cations in the soil (ZIGLIO; MIYAZAWA; PAVAN, 1999; FRANCHINI et al., 2003; DIEHL; MIYASAWA; TAKAHASHI, 2008). Furthermore, they change the order of adsorption of cations in the colloidal particles of soil, with higher leaching of di-and trivalent cations, such as $\mathrm{Al}^{3+}$, $\mathrm{Ca}^{2+}$ and $\mathrm{Mg}^{2+}$, in the form of an organo-metallic hydrosoluble complex (FRANCHINI et al., 1999; MIYAZAWA; PAVAN; FRANCHINI, 2002).

The quality and fertility of soils managed under a no-tillage system is related to the quantity and quality of crop residues produced, their rate of decomposition and the type and amount of nutrients released (TORRES; PEREIRA; FABIAN, 2008). These processes have a positive effect on the chemical properties of the soil (GUIMARÃES et al., 2008), favoring subsequent crops (SANTI; AMADO; ACOSTA, 2003; CALEGARI et al., 2008).

Potassium contained in vegetable residues is easily released, as it is not part of the composition of any organic compound or directly dependent on microbial action for decomposition, a result of its high solubility and ease migrating to the soil (ROSOLEM et al., 2006, 2007; TORRES; PEREIRA, 2008). The release of potassium from organic matter, according Rosolem, Calonego and Foloni (2003), depends more on the frequency and intensity of rainfall.

During biological decomposition of plant residues and straw cover, different organic acids are released that then dissociate, generating negative electric charges in the soil. These organic compounds have a preference for adsorbing cations with a higher positive charge, such as $\mathrm{Al}^{3+}, \mathrm{Ca}^{2+}$ and $\mathrm{Mg}^{2+}$, leaving potassium to be adsorbed by the negatively charged colloids (MIYAZAWA; 
PAVAN; FRANCHINI, 2002). This helps to reduce the movement of this nutrient in the soil profile.

Therefore, to better understand the effects of plant residues in soils managed under a no-tillage system, there is still a need for detailed studies evaluating the influence of organic acids released during decomposition of crop residues on the mobility of nutrients in the soil.

For this reason, this study was carried out to evaluate the influence of different types and doses of plant residues on the vertical mobility of potassium in soil columns.

\section{Material and Methods}

The trial was conducted in laboratory premises at the State University of Londrina, in the municipality of Londrina, Paraná State, Brazil.

The soil columns were assembled using samples of a Rhodic Hapludox (containing $630 \mathrm{~g} \mathrm{~kg}^{-1}$ clay) cultivated with napier grass (Pennisetum purpureum) over the previous 10 years. Separate samples were collected for layers at 0.0-0.10, 0.100.20 and $0.20-0.30 \mathrm{~m}$. Subsequently, subsamples of each layer were air dried, sieved using a 2.0 $\mathrm{mm}$ mesh and sent for chemical characterization (SPARKS et al., 1996). The results are presented in Table 1.

Table 1. Chemical characteristics of Rhodic Haplustox in each soil layer prior to setting up the experiment.

\begin{tabular}{|c|c|c|c|c|c|c|c|c|c|}
\hline Soil layer & pH & $\mathbf{P}$ & $\mathrm{Al}^{3+}$ & $\mathrm{Ca}^{2+}$ & $\mathbf{M g}^{2+}$ & $\mathbf{K}^{+}$ & SB & CEC & $\mathbf{V}$ \\
\hline (m) & $*$ & $\mathrm{mg} \mathrm{dm}^{-3}$ & ------ & ------- & $--\mathrm{cmol}$ & ----- & ------- & - & $\%$ \\
\hline $0.0-0.10$ & 4.8 & 26.40 & 0.0 & 3.8 & 3.0 & 0.89 & 7.69 & 13.39 & 57.4 \\
\hline $0.10-0.20$ & 5.0 & 20.00 & 0.0 & 4.1 & 2.4 & 0.56 & 7.06 & 11.96 & 59.0 \\
\hline $0.20-0.30$ & 4.9 & 6.10 & 0.0 & 2.6 & 2.5 & 0.38 & 5.48 & 10.70 & 57.0 \\
\hline
\end{tabular}

* $\mathrm{CaCl}_{2} 0.01 \mathrm{M}$.

Source: Elaboration of the authors.

Samples of the aerial parts of brachiaria (Brachiaria ruziziensis), sunflower (Helianthus annuus), lopsided oat (Avena strigosa), winter vetch (Vicia villosa), cultivated radish (Raphanus sativus) and wheat (Triticum aestivum), grown in the university's experimental area $\left(23^{\circ} 22^{\prime} \mathrm{S}, 51^{\circ} 10^{\prime} \mathrm{W}\right.$; elevation $585 \mathrm{~m}$ ), were collected in full flower, with the exception of wheat, which was collected during the final cycle (after grain harvesting). The plant material collected was then dried in a stove at $65^{\circ} \mathrm{C}$ for 48 hours, ground $(2 \mathrm{~mm})$ and chemically analyzed to determine $\mathrm{K}$ levels (MALAVOLTA; VITTI; OLIVEIRA, 1997). Average K levels for plant residue dry matter and doses applied to the soil are shown in Table 2.

Table 2. Potassium levels in the plant dry matter and quantities applied to the soil.

\begin{tabular}{|c|c|c|c|c|c|}
\hline \multirow[t]{2}{*}{ Plant residue } & \multirow[t]{2}{*}{$\mathrm{K}$ level in residue } & \multicolumn{4}{|c|}{$\begin{array}{c}\text { Dose of plant residue } \\
\left(\mathrm{Mg} \mathrm{ha}^{-1}\right)\end{array}$} \\
\hline & & 0 & 10 & 15 & 20 \\
\hline & $\left(\mathrm{g} \mathrm{kg}^{-1} \mathrm{MS}\right)$ & \multicolumn{4}{|c|}{$\mathrm{K}\left(\mathrm{kg} \mathrm{ha}^{-1}\right)$} \\
\hline $\mathrm{B}+\mathrm{S}$ & 23.42 & 0 & 234.2 & 351.3 & 468.4 \\
\hline Mix & 28.68 & 0 & 286.8 & 430.2 & 573.6 \\
\hline Cultivated radish & 31.38 & 0 & 313.8 & 470.7 & 627.6 \\
\hline Wheat & 18.77 & 0 & 187.7 & 281.5 & 375.4 \\
\hline
\end{tabular}

$\mathrm{B}+\mathrm{S}=$ brachiaria + sunflower. Mix $=$ mixture of cultivated radish + lopsided + oat + winter vetch.

Source: Elaboration of the authors. 
In order to conduct the experiment, columns of PVC (0.35 m high and $0.0508 \mathrm{~m}$, or 2" inner diameter) lined with plastic bags were prepared.
The columns were filled according to sample collection depth in an attempt to reproduce the natural distribution of the soil. The soil columns were then arranged in a steel rack (Figure 1).

Figure 1. Diagram of the rack used in the experiment.

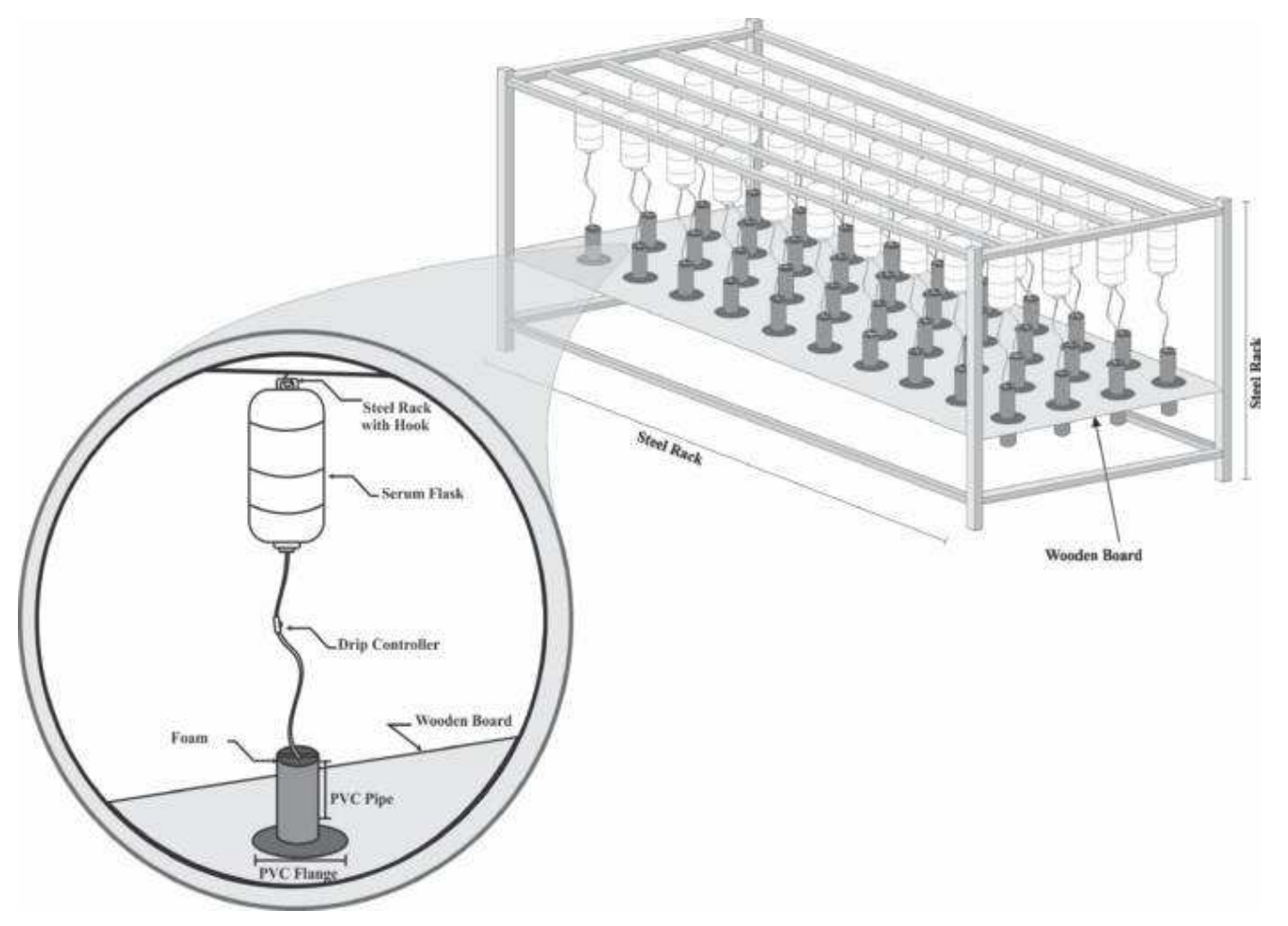

Source: Elaboration of the authors.

The ground $(2.0 \mathrm{~mm})$ residues were placed on the top of the soil columns in doses equivalent to the tested treatments (Table 2). The soil was then irrigated by dripping distilled water in a quantity equivalent to twice the pore volume, corresponding to an application of $192 \mathrm{ml}$ and equivalent to 95 $\mathrm{mm}$ rainfall per column. This was done by setting up drips at 30 drops per minute for approximately 4 hours.

Once watered, the columns were incubated for 10 days to allow reactions and saline balance to stabilize. After this period, the columns were disassembled and the earth was separated into layers corresponding to depths of $0.0-0.05,0.05$ $0.10,0.10-0.15,0.15-0.20,0.20-0.25$ and $0.25-0.30$ m. The samples obtained from each depth were dried and sieved (2.0 $\mathrm{mm}$ mesh) to determine levels of exchangeable K (SPARKS et al., 1996).

The experimental design was randomized, with 3 replications, and treatments were organized in a $4 \times 4$ factorial arrangement: 4 types of plant residue: $\mathrm{B}+\mathrm{S}$ (brachiaria and sunflower); Mix (cultivated radish + lopsided oat + winter vetch); cultivated radish; wheat; and 4 doses of $\mathrm{K}\left(0,10,15\right.$ and $\left.20 \mathrm{Mg} \mathrm{ha}^{-1}\right)$.

The results obtained for each soil layer were submitted to analysis of variance and the means were compared using Tukey's test at 5\% probability, or adjusted to equations by regression analysis using Statistical Analysis Software (SAS). 


\section{Results and Discussion}

K-content for the various soil layers was influenced $(p \leq 0.05)$ by the type and dose of plant residue (Table 3).

Table 3. Potassium levels in the soil layers as a function of type and dose of plant residue.

\begin{tabular}{|c|c|c|c|c|c|}
\hline \multirow{2}{*}{$\begin{array}{l}\text { Soil layer } \\
(\mathrm{m})\end{array}$} & \multirow{2}{*}{$\begin{array}{l}\text { Residue dose } \\
\left(\mathrm{Mg} \mathrm{ha}^{-1}\right)\end{array}$} & \multicolumn{4}{|c|}{ Plant residue } \\
\hline & & $\mathrm{B}+\mathrm{S}$ & Mix & Cultivated radish & Wheat \\
\hline & \multicolumn{5}{|c|}{ 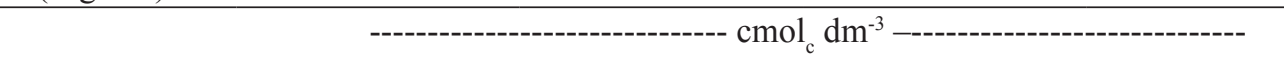 } \\
\hline $0.0-0.05$ & \multirow{6}{*}{0} & $0.76 \mathrm{a}$ & $0.80 \mathrm{a}$ & $0.80 \mathrm{a}$ & $0.85 \mathrm{a}$ \\
\hline $0.05-0.10$ & & $0.77 \mathrm{a}$ & $0.81 \mathrm{a}$ & $0.81 \mathrm{a}$ & $0.84 \mathrm{a}$ \\
\hline $0.10-0.15$ & & $0.57 \mathrm{a}$ & $0.59 \mathrm{a}$ & $0.59 \mathrm{a}$ & $0.65 \mathrm{a}$ \\
\hline $0.15-0.20$ & & $0.53 \mathrm{a}$ & $0.55 \mathrm{a}$ & $0.55 \mathrm{a}$ & $0.59 \mathrm{a}$ \\
\hline $0.20-0.25$ & & $0.44 \mathrm{a}$ & $0.43 \mathrm{a}$ & $0.43 \mathrm{a}$ & $0.50 \mathrm{a}$ \\
\hline $0.25-0.30$ & & $0.39 \mathrm{a}$ & $0.41 \mathrm{a}$ & $0.41 \mathrm{a}$ & $0.43 \mathrm{a}$ \\
\hline $0.0-0.05$ & \multirow{6}{*}{10} & $1.20 \mathrm{~b}$ & $1.88 \mathrm{ab}$ & $2.56 \mathrm{a}$ & $1.45 \mathrm{~b}$ \\
\hline $0.05-0.10$ & & $0.82 \mathrm{a}$ & $0.87 \mathrm{a}$ & $0.99 \mathrm{a}$ & $0.85 \mathrm{a}$ \\
\hline $0.10-0.15$ & & $0.62 \mathrm{a}$ & $0.64 \mathrm{a}$ & $0.65 \mathrm{a}$ & $0.66 \mathrm{a}$ \\
\hline $0.15-0.20$ & & $0.53 \mathrm{a}$ & $0.56 \mathrm{a}$ & $0.59 \mathrm{a}$ & $0.59 \mathrm{a}$ \\
\hline $0.20-0.25$ & & $0.43 \mathrm{a}$ & $0.46 \mathrm{a}$ & $0.46 \mathrm{a}$ & $0.49 \mathrm{a}$ \\
\hline $0.25-0.30$ & & $0.41 \mathrm{a}$ & $0.45 \mathrm{a}$ & $0.44 \mathrm{a}$ & $0.45 \mathrm{a}$ \\
\hline $0.0-0.05$ & \multirow{6}{*}{15} & $2.28 \mathrm{ab}$ & $2.64 \mathrm{ab}$ & $3.05 \mathrm{a}$ & $2.06 \mathrm{~b}$ \\
\hline $0.05-0.10$ & & $0.82 \mathrm{~b}$ & $0.92 \mathrm{ab}$ & $1.03 \mathrm{a}$ & $0.90 \mathrm{~b}$ \\
\hline $0.10-0.15$ & & $0.61 \mathrm{a}$ & $0.64 \mathrm{a}$ & $0.66 \mathrm{a}$ & $0.66 \mathrm{a}$ \\
\hline $0.15-0.20$ & & $0.55 \mathrm{a}$ & $0.51 \mathrm{a}$ & $0.58 \mathrm{a}$ & $0.55 \mathrm{a}$ \\
\hline $0.20-0.25$ & & $0.45 \mathrm{a}$ & $0.43 \mathrm{a}$ & $0.47 \mathrm{a}$ & $0.45 \mathrm{a}$ \\
\hline $0.25-0.30$ & & $0.42 \mathrm{a}$ & $0.42 \mathrm{a}$ & $0.46 \mathrm{a}$ & $0.45 \mathrm{a}$ \\
\hline $0.0-0.05$ & \multirow{6}{*}{20} & $2.81 \mathrm{ab}$ & $2.97 \mathrm{ab}$ & $3.41 \mathrm{a}$ & $2.41 \mathrm{~b}$ \\
\hline $0.05-0.10$ & & $0.89 \mathrm{c}$ & $1.18 \mathrm{ab}$ & $1.30 \mathrm{a}$ & $0.94 \mathrm{cb}$ \\
\hline $0.10-0.15$ & & $0.62 b$ & $0.67 \mathrm{a}$ & $0.70 \mathrm{a}$ & $0.68 \mathrm{a}$ \\
\hline $0.15-0.20$ & & $0.55 \mathrm{a}$ & $0.58 \mathrm{a}$ & $0.62 \mathrm{a}$ & $0.57 \mathrm{a}$ \\
\hline $0.20-0.25$ & & $0.45 \mathrm{a}$ & $0.47 \mathrm{a}$ & $0.49 \mathrm{a}$ & $0.48 \mathrm{a}$ \\
\hline $0.25-0.30$ & & $0.41 \mathrm{a}$ & $0.44 \mathrm{a}$ & $0.48 \mathrm{a}$ & $0.45 \mathrm{a}$ \\
\hline
\end{tabular}

$\mathrm{B}+\mathrm{S}=$ brachiaria + sunflower. Mix $=$ mixture of cultivated radish + lopsided + oat + winter vetch. Means followed by the same letter in the row did not differ according to Tukey's test at $5 \%$.

Source: Elaboration of the authors.

Plant residue influenced potassium content in the different soil layers, but the effects were only observed up to the 0.10-0.15 m layer (Table 3). However, if we consider the initial levels of potassium in the soil (Table 1), it can be inferred that increases occurred up to the $0.25-0.30 \mathrm{~m}$ layer, indicating that vertical mobilization of potassium varies as a function of the doses and residues considered. As the largest increments in exchangeable potassium were restricted to surface layers of the soil, this can be taken as an indication of the differential effects of the waste applied. According to Rosolem et al. (2006), the millet straw left on the surface releases potassium, which is leached up to $0.04 \mathrm{~m}$ deep by rainfall exceeding $30 \mathrm{~mm}$ but does not exceed 0.08 $\mathrm{m}$ deep for rainfall of $50 \mathrm{~mm}$. In our study we applied a quantity of water equivalent to that of a $95 \mathrm{~mm}$ rainfall on top of the plant residues, and the vertical 
movement of potassium was observed up to a depth of $0.30 \mathrm{~m}$. This can also be observed in Figure 2, which indicates increases in $\mathrm{K}$ in the different layers evaluated. Moreover, research by Franchini et al. (1999, 2001, 2003), Amaral, Anghinoni and Deschamps (2004) and Diehl, Miyasawa and Takahashi (2008) indicates that the potassium content of the residue and the amount and type of organic acids it releases can affect the mobility of cations in the soil. In addition to the decomposition of plant residues, organic acids are released and new negative charges are generated in the topsoil. These charges have a preference for adsorbing cations with a higher positive charge, such as aluminum, calcium and magnesium. Parallel to this process, an adsorption of the potassium released from the plant residues takes place. This phenomenon differs to the traditional model for the mobility of cations in the soil, but indicates that for areas where a notillage system is adopted, further studies should be conducted to assess more accurately the effects of accumulated mulch on the surface of the soil on the behavior of soil nutrients, especially those that are cationic.

Figure 2. Increases in potassium compared with initial levels in different soil layers as a function of dose and type of plant residue applied to the surface.

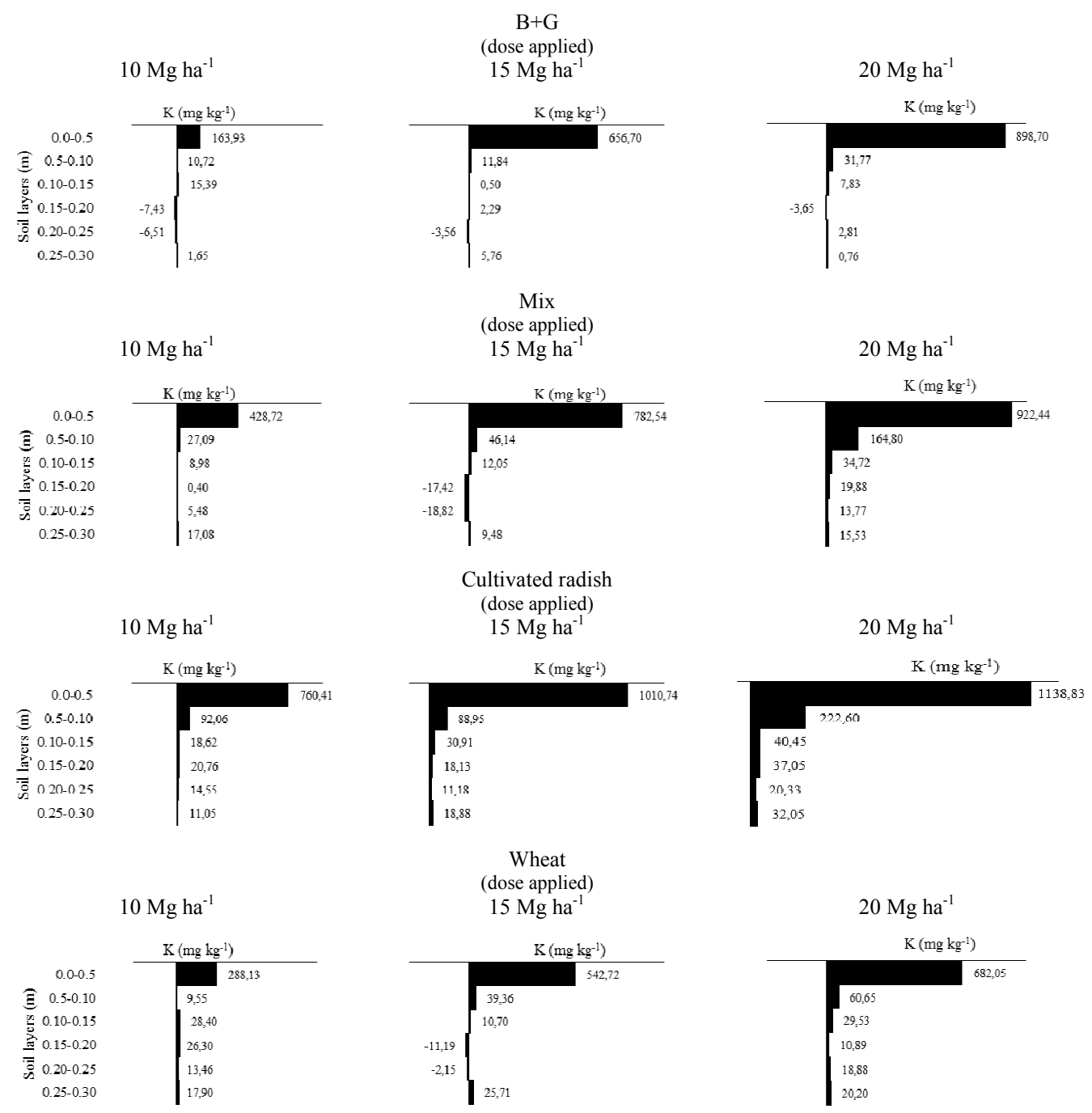

Source: Elaboration of the authors. 
From the application of $10 \mathrm{Mg} \mathrm{ha}^{-1}$ (Table 3), it was possible to observe significant variations in the amount of soil exchangeable potassium. This effect was more pronounced in the 0.0-0.05 m layer, especially with cultivated radish and Mix, which led to the biggest increases in levels of soil exchangeable potassium, differing from other plant residues tested.

For doses between 10 and $20 \mathrm{Mg} \mathrm{ha}^{-1}$, it was observed that increasing the amount applied increased the amount of potassium reaching progressively deeper layers, but significant effects only occur in the 0.01-0.25 m layer (Table 3), keeping the emphasis on the cultivated radish and Mix residues.

For soil layers below $0.15 \mathrm{~m}$, no significant differences were found between residues regardless of the dose considered.

These results are in agreement with those presented by Rosolem et al. (2006) in a study on changing the levels of exchangeable potassium restricted to upper soil layers. Furthermore, they also agree with the results obtained by Franchini et al. (1999), who found that crop residues of cultivated radish determined the greatest increases in exchangeable potassium in the soil surface layer (0.0-0.05 m).

In general, it can be concluded that crop residues of cultivated radish provided the largest increases in soil exchangeable potassium, followed by Mix and $\mathrm{B}+\mathrm{S}$, regardless of dose and soil layer considered. Cultivated radish residues increased potassium levels from 0.80 to $3.41 \mathrm{cmol}_{\mathrm{c}} \mathrm{dm}^{-3}$ in the $0.0-0.05 \mathrm{~m}$ surface layer (Table 3 ), corresponding to an increase of $326 \%$. The underperformance of wheat residues in increasing levels of exchangeable potassium in the soil is directly related to lower potassium content of these residues (Table 2).

According to observations by Franchini et al. (1999), this occurs because the decomposition of cultivated radish residues releases various organic acids that are able to remove the $\mathrm{Al}^{3+}$ and $\mathrm{Ca}^{2+}$ from colloidal particles of soil, releasing negative charges that adsorb potassium and promote a greater accumulation of this nutrient in the soil surface. This effect is very important, as according to Rosolem and Nakagawa (1985), potassium applications exceeding $80 \mathrm{~kg} \mathrm{ha}^{-1} \mathrm{yr}^{-1}$ of $\mathrm{K}_{2} \mathrm{O}$ result in leaching of potassium to the lower layers of the soil, which depending on soil type may reach the water table and contaminate groundwater supplies.

For the dose of $10 \mathrm{Mg} \mathrm{ha}^{-1}$, variations in levels of soil exchangeable potassium were observed. This effect was more pronounced in the 0.0-0.05 m layer and the cultivated radish and Mix crop residues caused the largest increases in soil exchangeable potassium levels compared with initial values. Generally speaking, vertical mobility of potassium increased as the amount of residues applied was increased, reaching deeper soil layers. More pronounced effects were observed up to a depth of $0.15 \mathrm{~m}$, and mainly for cultivated radish crop residues (Figure 2). In general, one can say that the cultivated radish crop residue provided the largest increases in soil exchangeable potassium, followed by Mix and $\mathrm{B}+\mathrm{S}$, regardless of dose and soil layer considered. Cultivated radish residues increased potassium levels from 0.80 to $3.41 \mathrm{cmol}_{\mathrm{c}} \mathrm{dm}^{-3}$ in the 0.0-0.05 m surface layer (Table 3 ), corresponding to an increase of $326 \%$.

To evaluate the effect of the dose, regression equations were adjusted (Table 4). It was found that for the first three layers evaluated (0.00-0.05, 0.05-0.10 and 0.10-0.15 m), significant adjustments for increases of soil exchangeable potassium were linear. These results are in agreement with those presented by Franchini et al. (1999) and Rosolem et al. (2006).

Therefore, it can be concluded that application of organic waste to the soil surface can contribute to increased soil potassium levels, reducing the need for application of inorganic fertilizers. 
Table 4. Regression equations for changes in potassium levels in the different soil layers as a function of residue dose.

\begin{tabular}{ccc}
\hline $\begin{array}{c}\text { Soil layer } \\
(\mathrm{m})\end{array}$ & Equation & $\mathbf{R}^{2}$ \\
\hline $0.0-0.05$ & $\mathrm{y}=0.1079 \mathrm{x}+0.7816$ & 0.9918 \\
$0.05-0.10$ & $\mathrm{y}=0.0122 \mathrm{x}+0.7835$ & 0.8504 \\
$0.10-0.15$ & $\mathrm{y}=0.0032 \mathrm{x}+0.6009$ & 0.9513 \\
\hline
\end{tabular}

$\mathrm{y}=$ Potassium level $\left(\mathrm{kg} \mathrm{ha}^{-1}\right), \mathrm{x}=$ dose of crop residue applied $\left(\mathrm{Mg} \mathrm{ha}^{-1}\right)$.

Source: Elaboration of the authors.

\section{Conclusions}

Surface application of crop residues alters the level of soil exchangeable potassium, particularly in the 0.0-0.05 m layer.

Increases in residue dose may significantly and linearly increase the level of exchangeable $\mathrm{K}$ in the $0.0-0.05,0.05-0.10$ and $0.10-0.15 \mathrm{~m}$ soil layers.

Superficial application of cultivated radish and Mix (cultivated radish + oat + winter vetch) residues led to the largest increases in exchangeable $\mathrm{K}$ levels, reaching layers of soil of $0.30 \mathrm{~m}$ deep.

Increases in potassium adsorption in the soil surface reduce the need for potassium fertilization and can reduce production costs and environmental pollution.

\section{Acknowledgements}

We would like to thank the National Council for Scientific and Technological Development (CNPq) and the Coordination of Improvement of Higher Education Personnel (CAPES) for grants awarded.

\section{References}

AMARAL, A. S.; ANGHINONI, I.; DESCHAMPS, F. C. Resíduos de plantas de cobertura e mobilidade dos produtos da dissolução do calcário aplicado na superfície do solo. Revista Brasileira de Ciência do Solo, Viçosa, MG, v. 28, n. 1, p. 115-123, 2004.

CALEGARI, A.; HARGROVE, W. L.; RHEINHEIMER, D. S.; RALISCH, R.; TESSIER, D.; TOURDONNET, S.; GUIMARÃES, M. F. Impact of long-term no-tillage and cropping system management on soil organic carbon in an Oxisol: a model for sustainability. Agronomy Journal, Madison, v. 100, n. 4, p. 1013-1019, 2008.

DIEHL, R. C.; MIYASAWA, M.; TAKAHASHI, H. W. Compostos orgânicos hidrossolúveis de resíduos vegetais e seus efeitos nos atributos químicos do solo. Revista Brasileira de Ciência do Solo, Viçosa, MG, v. 32, p. 2653-2659, 2008. Suplemento Especial.

FESCH, C.; LEHMAN, P.; HADERLEIN, S. B.; HINZ, C.; SCHARZENBACH, R. P.; FLUHLER, H. Effect of water content on solute transport in a porous medium containing reactive micro-aggregates. Journal of Contaminant Hydrology, Amsterdam, v. 33, n. 1-2, p. 211-230, 1998.

FRANCHINI, J. C.; HOFFMANN-CAMPO, C. B.; TORRES, E.; MIYAZAWA, M.; PAVAN, M. A. Organic composition of green manure during growth and its effect on cation mobilization in an acid Oxisol. Communications in Soil Science and Plant Analysis, New York, v. 34, n. 13-14, p. 2045-2058, 2003.

FRANCHINI, J. C.; MEDA, A. R.; CASSIOLATO, M. E.; MIYAZAWA, M.; PAVAN, M. A. Potencial de extratos de resíduos vegetais na mobilização do calcário no solo por método biológico. Scientia Agricola, Piracicaba, v. 58, n. 2, p. 357-360, 2001.

FRANCHINI, J. C.; MIYAZAWA, M.; PAVAN, M. A.; MALAVOLTA, E. Dinâmica de íons em solo ácido lixiviado com extratos de resíduos de adubos verdes e soluções puras de ácidos orgânicos. Pesquisa Agropecuária Brasileira, Brasília, v. 34, n. 12, p. $2267-$ 2276, 1999.

GUIMARÃES, M. F.; FONSECA, I. C. B.; BROSSARD, M.; PORTELLA, C. M. R.; BRITO, O. R.; RITCHIE, $\mathrm{J}$. Monitoring changes in the chemical properties of an Oxisol under long-term no-tillage management in subtropical Brazil. Soil Science, Baltimore, v. 173, n. 6, p. 408-416, 2008.

HESTERBERG, D. Biogeochemical cycles and processes leading to changes in mobility of chemicals in soils. Agriculture, Ecosystems \& Environment, Amsterdam, v. 67, n. 2-3, p. 121-133, 1998. 
KABATA-PENDIAS, A. Soil-plant transfer of trace elements: an environmental issue. Geoderma, Amsterdam, v. 122, n. 2-4, p. 143-149, 2004.

MALAVOLTA, E.; VITTI, G. C.; OLIVEIRA, A. S. Avaliação do estado nutricional das plantas: princípios e aplicações. 2. ed. Piracicaba: POTAFOS, 1997. 319 p.

MIYAZAWA, M.; PAVAN, M. A.; FRANCHINI, J. C. Evaluation of plants residues on the mobility of surface applied lime. Brazilian Archives of Biology and Technology, Curitiba, v. 45, n. 3, p. 251-256, 2002.

PADILLA, I. Y.; YEH, T. C.; CONKLIN, M. H. The effect of water content on solute transport in unsaturated porous media. Water Resources Research, Washington, v. 35, n. 11, p. 3303-3313, 1999.

QAFOKU, N. P.; SUMNER, M. E. Retention and transport of calcium nitrate in variable charge sub soils. Soil Science, Baltimore, v. 166, n. 5, p. 297-307, 2001.

ROSOlEM, C. A.; CALONEGO, J. C.; FOLONI, J. S. S. Lixiviação de potássio da palha de espécies de cobertura de solo de acordo com a quantidade de chuva aplicada. Revista Brasileira de Ciência do Solo, Viçosa, MG, v. 27 , n. 2, p. 355-362, 2003.

ROSOlEM, C. A.; CAlONEGO, J. C.; FOLONI, J. S. S.; GARCIA, R. A. Potássio lixiviado da palha de aveiapreta e milheto após a dessecação química. Pesquisa Agropecuária Brasileira, Brasília, v. 42, n. 8, p. 11691175, 2007.

ROSOLEM, C. A.; NAKAGAWA, J. Potassium uptake by soybean as affected by exchangeable potassium in soil. Communications in Soil Science and Plant Analysis, New York, v. 16, n. 7, p. 707-726, 1985.

ROSOLEM, C. A.; SANTOS, F. P.; FOLONI, J. S. S.; CALONEGO, J. C. Potássio no solo em consequência da adubação sobre a palha de milheto e chuva simulada. Pesquisa Agropecuária Brasileira, Brasília, v. 41, n. 6, p. 1033-1040, 2006.
SANTI, A.; AMADO, T. J. C.; ACOSTA, J. A. A. Adubação nitrogenada na aveia preta. I - influência na produção de matéria seca e ciclagem de nutrientes sob sistema plantio direto. Revista Brasileira de Ciência do Solo, Viçosa, MG, v. 27, n. 6, p. 1075-1083, 2003.

SOLLINS, P.; ROBERTSON, G. P.; UEHARA, G. Nutrient mobility in variable-charge and permanentcharge soils. Biogeochemistry, Dordrecht, v. 6, n. 3, p. 181-199, 1988.

SPARKS, D. L.; PAGE, A. L.; HELMKE, P. A.; LOEPPERT, R. H.; SOLTANPOUR, P. N.; TABATABAI, M. A.; JOHNSTON, C. T.; SUMMER, M. E. Methods of soil analysis: part 3. Chemical methods. 3. ed. Madison: Soil Science Society of America, 1996. 1390 p. (Soil Science Society of America Book Series, 5).

TISDALE, S. L.; NELSON, W. L.; BEATON, J. D. Soil fertility and fertilizers. 4. ed. New York: MacMillan Publishing Company, 1985. 754 p.

TORRES, J. L. R.; PEREIRA, M. G. Dinâmica do potássio nos resíduos vegetais de plantas de cobertura no cerrado. Revista Brasileira de Ciência do Solo, Viçosa, MG, v. 32, n. 4, p. 1609-1618, 2008.

TORRES, J. L. R.; PEREIRA, M.; FABIAN, A. J. Produção de fitomassa por plantas de cobertura e mineralização de seus resíduos em plantio direto. Pesquisa Agropecuária Brasileira, Brasília, v. 43, n. 3, p. 5-12, 2008.

ZIGLIO, C. M.; MIYAZAWA, M.; PAVAN, M. A. Formas orgânicas e inorgânicas de mobilização do cálcio no solo. Brazilian Archives of Biology and Technology, Curitiba, v. 42, n. 2, p. 257-262, 1999. 
